\title{
FINANCING AMERICAN WAR ORDERS
}

\author{
By Thomas Conway, JR., Ph.D., \\ Professor of Finance, Wharton School of Finance and Commerce, \\ University of Pennsylvania.
}

War orders have revolutionized America's position in international affairs. In point of age and development, the United States is a young country. It is scarcely two generations since the west was settled. We have needed large amounts of capitalmore than could be provided from the savings of our people. Our natural resources, favorable climate and energetic population have furnished a combination which has been attractive to investors of all nations. The great commercial nations of Europe, especially England, France and Germany, have in the past years invested enormous amounts of money in this country. America, therefore, might be compared to a thriving, growing industrial plant for the construction of which large amounts of money had to be borrowed and on which there still remains a large mortgage. The plant has earned large profits, enabling it not only to pay interest upon the borrowed money but to return handsome dividends to its stockholders. War orders are enabling America to pay off rapidly the mortgage on the plant. We are ceasing to be a debtor nation and are approaching the position where we will become one of the great creditor nations of the world.

Whatever may be the merits of the question as to whether the United States is preserving neutrality in selling munitions of war to one set of belligerents, the other being debarred because of the blockade, there can be no doubt that, from an economic standpoint, America is one of the strongest factors in the Allies' struggle. Without her material assistance, the chances of success for the Allies would be perhaps hopelessly reduced. The workshops of America have turned out an enormous supply of goods of every character directly or indirectly employed in warfare. Every American workman engaged in such work is taking the place of a citizen of a belligerent country who would otherwise have to remain at home in the factories in order that the necessary munitions 
might be produced. American workmen, in this sense, therefore may be regarded as substituting for European soldiers. It is not the purpose of this article, however, to deal with the international aspects of the munitions business. The question is one for determination according to the principles of international law. However, it is important for us to understand the reason why the Allies turned to the United States, just as the central powers would have done were they able to control the seas-for supplies of munitions.

\section{The Immense Volume of War Materials Exported}

It is almost impossible to determine the exact extent of the war orders which have placed in America. They surpass in volume anything imagined prior to the European conflict. The sudden outbreak of war paralyzed American business. A large proportion of the English merchant marine was requisitioned for military purposes. German shipping was driven from the seas. What in substance amounted to a blockade was established around Germany, cutting off one of our largest foreign customers. Thousands of men were out of employment. Relief committees and other philanthropic organizations were swamped with demands for assistance to the unemployed. The paralysis of international exchange, the closing of the stock exchanges throughout the entire world, and the dislocation of trade relations affecting most of the civilized countries profoundly depressed all forms of business enterprise. Factories were running on part time or were completely shut down. These conditions were peculiarly favorable to the nations urgently in need of war munitions of every character. American manufacturers were anxious to do business; work upon orders could be undertaken at once. Thus it happened that within a few weeks after the outbreak of the war, America's industrial condition began to be revivified by the injection of war business which has since become the outstanding feature of our commercial and industrial life.

The extent of war orders and the influence which they have exerted upon industrial conditions in this country can be understood if we set down for comparison the amount of goods of this character which had been exported prior to and since the outbreak of the war. We will first make a comparison of the exportations of those articles which are obviously used in military operations: 
Articles Exported

Horses. . . . . . . . . . . . . .

Mules.

Horse shoes . . . . . . . . . . . . .

Aeroplanes and parts of .......

Automobiles and parts of (not including engines and tires)...

Automobile tires.............

Railway cars, carriages, motor cycles, bicycles, wheelbarrows and hand trucks.......

Explosives. . . . . . . . . . . . .

Barbed wire. . ............

Boots and shoes...........

Harness and saddles. ........

Firearms ...............

Surgical appliances, including instruments..............
1914

Twelve Months Ending June

1014

$\$ 3,388,819$

690,974

$98,835^{*}$

226,149

$33,198,806$

$3,505,267$

$51,676,222$

$6,272,197$

$4,039,590 *$

$17,867,234$

786,455

$3,442,297^{*}$

$\frac{1,494,888}{\$ 118,900,590}$

1915

(Value.)

$\$ 64,046,534$

$12,726,143$

$2,001,258^{*}$

$1,541,446$

$\$ 73,531,146$

$22,946,312$

$2,135,079 *$

$7,002,005$

$$
\begin{array}{r}
68,107,818 \\
4,963,270
\end{array}
$$

$120,000,866$

$17,936,227$

$\$ 118,900,590 \quad \$ 324,545,357 \quad \$ 933,632,002$

*In footing the totals, duplications, indicated above by $\left(^{*}\right)$, have been avoided.

In passing it should be noted that war broke out in Europe on July 28, 1914. By comparing the value of exports of each of the articles enumerated above for the twelve months ending June 30,1914 , with the amount exported in the two succeeding years, the extent of the stimulus which war has imparted to those industries can be measured. It will be seen that whereas in the year ending June 30,1914 , the total value of the above mentioned articles exported was $\$ 118,900,590$, the amount exported in the year ending June 30,1915 , was $\$ 324,545,357$; while in the year ending June 30,1916 , they aggregated $\$ 933,632,000$.

\section{Exports of Indirect Military Value}

War orders are variously defined and according to the definition the volume of such business will vary. If a narrow construction is applied, the term being used to include merely those articles which are used directly and unmistakably in military operations, their volume would be compassed within the above table. But an accurate construction of the term would involve the inclusion of a large number of articles which are not directly 
employed in military operations. War involves the destruction not only of men but of a large amount of property which, in times of peace, would be used in gainful occupations. It involves the demoralization of labor forces, for the places of those taken to the front must be filled by inexperienced men; or in many cases remain vacant. Modern war has for its background a tremendous and Herculean business organization engaged in the production of food, clothing, ammunition, weapons and supplies of every character necessary to effective operations of armies numbering millions of men. Industries of every great belligerent have been largely remade. Factories which have produced cloth, for example, have been ripped out and converted into metal working shops. Other textile factories have, through changes in machinery and methods, been adapted to the production of uniforms, in which work special requirements must be met. Thus it follows that America has furnished not only an enormous quantity of goods directly useful in war, but she has been called upon to furnish a large amount of machinery and equipment of every kind which is necessary for the reconstruction of European industry or for substitution for goods which in peaceful times were produced by one or the other of the belligerents.

One of the most easily understood illustrations is foodstuffs. When France called millions of men to the colors, she depopulated her farms. It became necessary, therefore, to import a larger supply of foodstuffs than had theretofore been necessary. If we compare the exports of articles which are indirectly used in warfare, we will find that there has been an enormous expansion in this portion of the export business of the United States, which must be classified as a part of our war orders:

Articles exported

Brass, articles made from ......

Breadstuffs ...............

Copper and manufactures of (except ore) .............

Manufactures of cotton.......

Metal working machinery ......

Total iron and steel and manu-

factures of . . . . . . . . . .

Meat products............
1914

Twelve months ending June 1915
(value)

$165,302,385$

$146,222,556$

$51,467,233$

$14,011,359^{*}$

$251,480,677$

$143,261,846$
$\$ 12,819,373$

$573,823,676$

$99,558,030$

$71,974,497$

$28,162,968^{*}$

$\$ 128,331,820$

$435,696,629$

$173,946,226$

$112,053,127$

$61,315,032^{*}$

$225,861,387$

$621,209,453$

$205,785,468$ 
Articles exported

Zinc and manufactures of (except ore and dross) ..........

Wool and manufactures of (including wearing apparel).....

Cotton wearing apparel ........
$1914 \begin{gathered}\text { Twelve months ending June } \\ 1915 \\ \text { (value) }\end{gathered}$

1916

$\$ 406,208 \quad \$ 21,243,935 \quad \$ 45,867,156$

$4,790,087 \quad 27,327,451 \quad 53,983,655$

$10,767,448^{*} \quad 29,550,090^{*} \quad 34,226,664^{*}$

$\$ 766,897,637 \$ 1,238,393,817 \$ 1,838,324,012$

* In footing the totals, duplications, indicated above by $\left({ }^{*}\right)$, have been avoided.

Combining the totals in the two preceding tables, we find that the volume of exports of those articles now directly or indirectly used in warfare had amounted to $\$ 885,798,227$ in the year ending June 30,1914 . In the year ending June 30, 1915-the first year of war the total was $\$ 1,562,939,174$ while in the year ending June 30,1916 the total was $\$ 2,771,956,014$. The increases in the amount thus exported in the last two years over the exports for the year ending June 30,1914 , is a rough measure of the war orders which America has filled:

Year ending June 30

1915 .

$\$ 677,141,000$

1916 . $1,886,158,000$

$\$ 2,563,299,000$

The increase in America's export trade has been almost entirely confined to the articles enumerated above. The value of all other classes of merchandise, not specifically enumerated above, exported from the United States in the two years of war, as compared with the year preceding the outbreak of the war, was as follows:

Year ending June 30

1914

$\$ 1,443,885,798$

1915 $1,153,239,291$

1916 .

$1,500,441,760$

Under ordinary conditions, the British blockade would have resulted in a material reduction in American export trade because it would have cut off Germany and her allies, numbered among our largest customers. As a matter of fact, the tremendous expansion of American trade is all the more remarkable because it 
occurred in the face of the loss of the trade of the central powers. The comparative exports of all classes from the United States to the two groups of belligerents during the year preceding the outbreak of the struggle and the first two years of war are as follows:

Value of Exports of Merchandise

\begin{tabular}{|c|c|c|c|}
\hline \multirow[b]{2}{*}{ Central Powers: } & \multicolumn{2}{|c|}{1914 Twelve months ending June } & \multirow[t]{2}{*}{1916} \\
\hline & & & \\
\hline Austria-Hungary & $\$ 22,718,258$ & $\$ 1,238,669$ & $\$ 152,929$ \\
\hline Bulgaria . . . . . . & 326,734 & 12,490 & 44,223 \\
\hline Germany . . . . . . . . . & $344,794,276$ & $28,863,354$ & 288,851 \\
\hline Turkey .............. & $3,328,519$ & 994,120 & 42,169 \\
\hline Totals. & $\$ 371,167,787$ & $\$ 31,108,633$ & $\$ 528,172$ \\
\hline
\end{tabular}

The Allies:

\begin{tabular}{|c|c|c|c|}
\hline Belgium. & $\$ 61,219,894$ & $\$ 20,662,315$ & $\$ 21,844,638$ \\
\hline France. & $159,818,924$ & $369,397,170$ & $630,672,5$ \\
\hline Italy. & $74,235,012$ & $184,819,688$ & $270,489,9$ \\
\hline Russia. & $31,303,149$ & $60,827,531$ & $313,515,3$ \\
\hline United Kingdom & $594,271,863$ & $911,794,954$ & $1,518,046,2$ \\
\hline
\end{tabular}

The Allies' blockade has practically isolated the Central Powers. Their exports have fallen to a negligible point. On the other hand, the purchases of the Allies from us have nearly trebled. The problem of financing war orders in America, therefore, relates almost entirely to the purchases of the Allies.

\section{International Financing Before the War}

An understanding of the financial problems involved in paying for American war orders depends upon a comprehension of the general principles underlying the payment of debts between citizens of different countries. It is an axiom of business that international indebtedness, whether public or private, is settled almost entirely by the exchange of goods, giving rise to banking credits. Whatever balance there may be after these credits are exhausted is liquidated through the shipment of gold. The account of the United States with the rest of the world may be illustrated by reproducing the comparison made by Sir George Paish for our National Monetary Commission some years ago: 
Foreign Trade of the United States, 1908-9

Merchandise:

Exports-

Domestic . . $\$ 1,638,000,000$

Foreign.... 25,000,000

Total. ........... \$1,663,000,000

Imports............... 1,312,000,000

Excess of merchandise exports over imports $\$ 351,000,000$

Gold:

Exports................ \$92,000,000

Imports............... $44,000,000$

Excess of gold exports over imports . . . . \$ \$8,000,000

Silver:

Exports................ \$56,000,000

Imports............... $44,000,000$

Excess of silver exports over imports ..... \$12,000,000

Total excess of merchandise, gold and silver exports over imports................................ \$411,000,000

Remittances for interest, etc.:

Interest . . . . . . . . . . . . . . . . . . . $\$ 250,000,000$

Tourist expenditures................ 170,000,000

Remittances to friends............... 150,000,000

Freight......................... 25,000,000

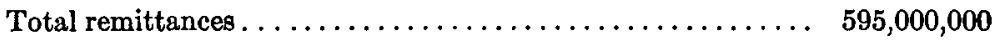

Excess of sum remitted for interest, tourists, to friends, and for freight over trade balance . . . . . . . . . . . $\$ 184,000,000$

Sir George Paish estimated that the above balance of $\$ 184$,000,000 was liquidated or settled by permanent or temporary investments made by citizens of other countries in the United States. A word of explanation concerning the above tabulation may be helpful. America, for a generation, has been exporting much more than she has imported, resulting in what is known as a "favorable balance of trade." This favorable balance of trade or excess of exports over imports, which in the year under consideration amounted to some $\$ 411,000,000$, is eaten up through payments 
which citizens of this country must make to foreigners for various purposes. The first item represents interest payments on foreign capital invested in this country, amounting to some $\$ 250,000,000$. To this must be added the tourist expenditures of our citizens who, in peaceful times, went abroad for the summer. The excess of their expenditures over those of Europeans visiting this country was estimated at $\$ 170,000,000$. The item "remittances to friends" represented assistance given by American immigrants to their relatives in the mother country. Inasmuch as most of America's oversea trade is handled in ships flying other flags, it follows that we must pay some $\$ 25,000,000$ a year for freight.

The situation which Sir George Paish depicted in his comparison for the year 1908-09 is generally representative of the conditions which prevailed at the outbreak of the war. The trade balance of the United States, that is to say the excess of exports over imports, including not only merchandise but gold and silver, in succeeding years, was as follows:

Year ending June 30

1910

$\$ 273,330,267$

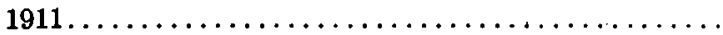

$489,809,443$

$1912 \ldots \ldots \ldots \ldots \ldots \ldots \ldots \ldots \ldots \ldots \ldots \ldots \ldots \ldots \ldots \ldots$

$577,289,769$

1913

$691,790,307$

$1914 \ldots \ldots \ldots \ldots \ldots \ldots \ldots \ldots \ldots \ldots \ldots \ldots \ldots \ldots$

$540,791,780$

According to the best estimates, America's fixed charges payable to Europe, representing remittances for goods purchased, tourist expenditures, remittances from Americans to friends residing abroad, remittances for freight, insurance, etc., remained in the neighborhood of $\$ 600,000,000$ per annum. This sum might be termed the United States' fixed charges which every year must be liquidated by an excess of merchandise exports over imports. When this excess has been less than $\$ 600,000,000$, the deficiency has been made up through the exportation of gold from this country or the sale of additional American securities to European investors. When the balance of trade of the United States exceeds $\$ 600$,000,000 , Europe must either ship us gold or sell securities in our markets. As a matter of fact under normal conditions, as we have seen, the balance of trade corresponds very closely to what we have termed the fixed charges of the United States. 


\section{Changes Brought About by the War}

With the advent of war orders, the situation was entirely revolutionized. The following comparison will show how abnormal became our trade relations with the rest of the world:

\begin{tabular}{|c|c|c|c|}
\hline $\begin{array}{c}\text { Year ending } \\
\text { June } 30\end{array}$ & Merohandise exports & $\begin{array}{c}\text { Merchandise } \\
\text { imports }\end{array}$ & $\begin{array}{l}\text { Excess of exports } \\
\text { over imports }\end{array}$ \\
\hline $1914 .$. & $\$ 2,364,579,148$ & $\$ 1,893,925,657$ & $\$ 470,653,491$ \\
\hline 1915. & $2,768,589,340$ & $1,674,169,740$ & $1,094,419,600$ \\
\hline 1916. & $4,333,658,865$ & $2,197,883,510$ & $2,135,775,355$ \\
\hline
\end{tabular}

To settle this abnormal excess of exports over imports, totaling in the two years of war in the neighborhood of $\$ 2,300,000,000$ (a sum roughly equal to the exportations of munitions of war), constitutes the financial problem of paying for American war orders. There are three methods by which a nation may settle an unfavorable balance in account with the rest of the world. The first is the exportation of gold, for gold is the international money of commerce. The second method is through the sale of securities in the markets of a creditor nation, the proceeds of which may be used to liquidate the balance of debt owing to that nation. The third method is to borrow a sum equal to the remaining indebtedness in the creditor country or in some other country from which the proceeds of the loan may be transferred to the creditor country to settle the indebtedness. All of these methods have been employed for many years. They have been used to an extent heretofore undreamed of in financing American war orders.

In view of the fact that Germany was cut off from America by the blockade, the problem of financing war orders concerns almost entirely the purchases of England for herself and her allies. It should be noted that at an early date England, by arrangement with her allies, assumed control of the matter of financing American purchases. Most of the financial operations have been carried on through the firm of J. P. Morgan \& Company, acting as fiscal agents for the British government.

\section{The Procedure Followed in War Financing}

The procedure followed in financing American war orders can be divided into certain phases, each of which is more or less clearly defined, although in point of time overlapping. Immediately following the declaration of war, American bankers were embarrassed 
by the necessity of providing gold for exportation to Europe in settlement of American debts. America for years had been in the habit of making short-time loans in foreign money markets during the spring and summer, to be repaid through the sale of cotton and other staples exported in the fall and early winter. It has been estimated that such borrowings were usually in the neighborhood of $\$ 400,000,000$. Pressed as they were for funds, European bankers demanded repayment of these loans, while at the same time the uncertainty at the beginning of the struggle for command of the sea drove British and German ships alike to seek the safety of the most convenient harbors. Our foreign trade was paralyzed. Grain, cotton and freight of every character piled up at the seaboard and congested railway yards and terminals throughout the country. American bankers found themselves in the position of having loans to repay without being able to avail themselves of the proceeds of our customary export trade which would normally move at that season of the year. The only alternative which was open to them-for European and American stock exchanges were closed and hence the sale of securities could not be resorted towas the exportation of gold. During the first few weeks following the outbreak of the war, gold moved to Europe in large quantities. The net loss to this country from August 1 to December 31, 1914, amounted to $\$ 81,720,000$.

As a matter of fact, the outflow of gold was checked somewhat prior to the close of the year 1914. The reëstablishment of ocean communication and the lessening of the rigors of the British moratorium made available sufficient credits, shortly after the first of November, to enable American bankers to meet their obligations without the exportation of gold. Sterling exchange reached $\$ 4.86 \frac{3}{4}$ on November 12 , indicating practically normal conditions. In the meantime, Europe had been placing enormous war orders in America. The financial requirements necessary to meet these commitments and the realization that Europe's purchases of foodstuffs and raw materials would be greater than ever, led American bankers to believe that the worst was over, in so far as preserving a stable financial equilibrium was concerned. Accordingly, on November 28,1914 , the stock exchange was opened, with limitations upon trading designed to prevent wholesale liquidation at ruinous prices. These limitations were shortly thereafter removed. 


\section{Purchases in America and Their Effects}

The enormous purchases of the Allies in America speedily turned the tables, so that instead of having to export gold and face a sterling exchange rate of $\$ 5$, America was in a position where British exchange sold down to unheard of levels, touching the low point at $\$ 4.49$ on September 4,1915 . An enormous importation of gold occurred. From surface indications one might have concluded that financial England was dangerously near a state of demoralization in handling the exchange problem. Apparently there were no adequate means of creating the necessary credits in America. In the absence of any authentic explanation, various reasons have been given for England's apparent lack of policy controlling the exchange markets. One explanation which has been offered is that England over-estimated the extent of the liquidation in the New York market by foreigners of American securities owned by them. As a matter of fact, whatever may be the real reason, the fact remains that the inflow of gold continued in very large quantities, reducing the reserve at the Bank of England to a point which in peace times would have been considered dangerous. It was evident that the Allies must devise other methods to finance their American purchases.

It should be added parenthetically that the importation of gold has continued at irregular intervals throughout the entire period since the outbreak of the war. Gold has moved to this country whenever other methods of financing American purchases have been insufficient, and it is reasonable to suppose that we have not yet reached the end of such gold importations. The record of gold imports and exports, together with the net loss or gain throughout the period of war compares as follows:

Gold Imports and Exports

(000 Omitted)

\begin{tabular}{|c|c|c|c|}
\hline Time & Exports & Imports & $\begin{array}{c}\text { Net movement } \\
+ \text { or - }\end{array}$ \\
\hline Aug. 1914 to Dec. $31,1914 \ldots$ & $\$ 104,973$ & $\$ 23,253$ & $\$-81,720$ \\
\hline Jan. 1, 1915 to July $2,1915 \ldots$ & 6,266 & 146,960 & $+140,694$ \\
\hline Jul 2,1915 to Dec. $31,1915 \ldots$ & 24,727 & 304,995 & $+280,268$ \\
\hline Jan. 1, 1916 to June $30,1916 \ldots$ & 67,291 & 190,149 & $+122,858$ \\
\hline
\end{tabular}

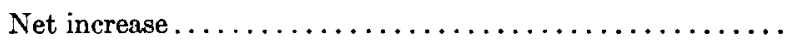


The net addition to the gold stock of the United States from the outbreak of the war to June 30,1916 , was $\$ 462,100,000$.

In point of aggregate amount, the shipment of gold to the United States in settlement for war purchases was the least important method employed. By far the larger part of the tremendous balance which the allied nations owed us has been paid through the sale of securities in American markets, creating credits which could be utilized in payment of these enormous debts. The securities sold in this market consisted of two classes: (1) the sale of government bonds and other obligations created by the belligerent nations to finance the war; and (2) the re-sale in America of European holdings of our securities.

\section{Flotation of Foreign Government Loans}

The flotation of foreign government loans in America has been accomplished under conditions not altogether favorable. American investors have a natural prejudice against putting their money into projects located at a distance. The average bond buyer prefers the security of a corporation situated near his home to one conducting business in a distant part of the country. When he is asked to put his money into some enterprise in a foreign land, he has shown little enthusiasm for the project. It was, therefore, a rather difficult matter to make a market for large amounts of European government securities. During the period when large gold shipments were being made to America, European bankers had effected short-time credits with American financial institutions. As the maturity of these short-time loans approached, it became imperative that they should be funded by some more permanent method of financing. J. P. Morgan \& Company, as the fiscal agents of the Allies, after extended negotiations, formed a syndicate which floated $\$ 500,000,000$ of bonds representing the joint obligations of the English and French governments, bearing 5 per cent interest and maturing within five years. These bonds were offered at 98 . Looked at from a strictly technical viewpoint, the loan was only moderately successful. The bonds have never sold up to the issuing price. A great deal of hard work was necessary to get the investing public to absorb them. However, in view of the unfamiliarity of American investors with foreign loans and the prejudices which existed, the success of the loan was probably as good as could be expected. 
The Anglo-French loan was followed by the sale of a number of smaller issues and the creation of short-time credits. The New York Journal of Commerce has prepared the following summary of the foreign loans effected in America from the outbreak of the war to June 30,1916 :

\section{Edropean Loans Negotiated in the United States}

August 1, 1914 to June 30, 1916

Anglo-French governments $5 \%$-year bonds . . . . . . . . . .

British banking credit for six months at $4 \frac{1}{2} \%$, renewed for 12 months at $5 \%$.

French government:

Treasury notes, $5 \%$ one year (paid) . . . . . . . . . .

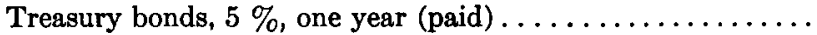

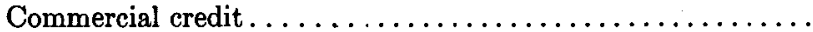

Collateral loans made through Rothschild's and secured by

Penna. R. R. and St. Paul R. R. bonds (paid) . . . . . . .

Acceptance credit for one year . . . . . . . . . . . . . .

Additional acceptance credit. . . . . . . . . . . . . . .

Russian government:

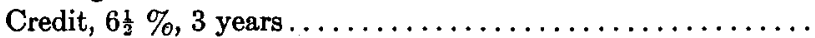

Acceptances (paid) . . . . . . . . . . . . . . . . . .

Credit to Russian-Asiatic bank . . . . . . . . . . . . .

Treasury notes $5 \%$, one year (paid) . . . . . . . . . .

Banking credits, private arrangements . . . . . . . . . . .

Italian government bonds, $6 \%, 1$ year $\ldots \ldots \ldots \ldots \ldots$

German government:

Notes, 5 per cent, 9 months (paid) . . . . . . . . . . .

Notes $(6 \%$ basis) due April, $1917 \ldots \ldots \ldots \ldots \ldots \ldots \ldots \ldots$

Banking credit (estimated) $\ldots \ldots \ldots \ldots \ldots \ldots \ldots \ldots \ldots$

Swiss government, notes $5 \%, 1,3$ and 5 years. . . . . . . .

Greek government, loans negotiated with banks...........

Swedish government, notes, $6 \%, 2$ years . . . . . . . . . .

Norwegian government:

Bonds, $6 \%, 7$ years.

$\$ 500,000,000$

$50,000,000$

$10,000,000$

$30,000,000$

$20,000,000$

$30,000,000$

$15,000,000$

$15,000,000$

$50,000,000$

$25,000,000$

$25,000,000$

$10,000,000$

$7,000,000$

$25,000,000$

$10,000,000$

$10,000,000$

$6,000,000$

$15,000,000$

$7,000,000$

$5,000,000$

Notes, $6 \%, 2$ and 3 years...................

$5,000,000$

$3,000,000$

Miscellaneous loans and banking credits (estimated).

$27,000,000$

Total

$\$ 900,000,000$

The aggregate face value of the loans negotiated in America (presuming that the statement of the Journal of Commerce includes all of the loans negotiated) is $\$ 900,000,000$. If we add to this total the excess of gold importations in America over exportations from this country of $\$ 462,100,000$, we have a total of. $\$ 1,362,100,000$. 
Comparing this with the abnormal trade balance of $\$ 2,500,000,000$, representing Europe's war bill due this country, we see that there remains to be financed payments aggregating some $\$ 1,200,000,000$. Unless there had remained to the Allies some other method of effecting such payments, they would of necessity have been compelled to restrict their war purchases to the total sum indicated.

\section{European Holdings of American Securities}

The greatest resource which the allied nations possessed in meeting their bills was their ability to sell American securities, held by their citizens, in our markets, thereby creating credit balances which could be used in the settlement of debts owing to us. The extent of European holdings in American securities has been the subject of much speculation. The most authoritative statement which we possess is that prepared by Sir George Paish for our National Monetary Commission in 1910:

Great Britain possesses about $\$ 3,500,000,000$ of American securities. To this sum has to be added the considerable amounts invested by the continent. Large amounts of German, Dutch, and French capital are embarked in American undertakings, principally railways. A statement drawn up in 1902 at the instance of the French Minister of Finance from reports supplied by French diplomatic agents and consuls in various parts of the world placed the total amount of French capital invested at that time in the United States at $600,000,000$ francs, or $\$ 120,000,000$, but this figure appears to have been an underestimate. It is true that few issues of American securities are publicly quoted on the Paris Bourse, but relatively large amounts have been purchased privately by French investors in London and in New York. The French investments in the United States, including the Pennsylvania Railroad and other loans placed in Paris since 1902, amount to nearly $2,500,000$ francs, or $\$ 500,000,000$.

Estimates of the amount of capital invested by Germany in the United States were made in 1905 by the German Admiralty and published in a work entitled Die Entwicklung der Deutschen Seeinteressen im letzten Jarhzehnt. These estimates placed the amount of German capital in the Unitcd States and Canada in 1904 at from $2,500,000,000$ marks to $3,000,000,000$ marks, say, $\$ 625,000,000$ to $\$ 750,000,000$. Since 1904 , considerable additional sums of German capital have been invested in the United States. German bankers place the amount of the German investments in American securities at about $\$ 1,000,000,000$. The amount of Dutch capital in the United States is about $\$ 750,000,000$. American securities are also held in Belgium, Switzerland, and in other countries. In the aggregate the amount of European capital invested in "permanent" securities in the United States is approximately $\$ 6,000,000,000$. 
It is generally believed that no great change occurred in the volume of European investments in America from the date of this estimate to the outbreak of the European war. What proportion of these investments can be re-sold is a matter concerning which no definite information is at hand. A very considerable proportion of the total is represented by the ownership of land, small manufacturing enterprises and unlisted securities for which no ready market exists and which therefore must be disposed of slowly and by individual bargain. The most readily available portion of European holdings consists of American railroad stocks and bonds and of the securities of certain great industrials listed on the stock exchange and for which an active market ordinarily exists. No authoritative computation has been made of the extent of such industrial investments.

The only data which we have concerning the extent of European liquidation relate to the holdings of railroad securities. Mr. L. F. Loree, President of the Delaware and Hudson Company, has made three inquiries since the outbreak of the war of some 144 railroads-being all of the roads in the United States over 100 miles in length - as to the amount of their securities standing in the names of foreign owners. The results of his three inquiries are as follows:

\section{American Railroad Securities Held Abroad}

Class of security

Preferred stock.............

Second preferred stock.........

Common stock . . . . . . . . . . .

Notes....................

Debenture bonds.............

Collateral trust bonds. . . . . . . .

Mortgage bonds..............

Equipment trust bonds. . . . . . . .

Car trusts .................

Receivers' certificates.........

Total.

Jan. $\$ 1,1916$

$\$ 204,394,400$

$5,558,150$

$573,880,393$

$58,254,390$

$187,508,310$

$282,418,415$

$1,371,156,851$

$20,233,455$

.........

998,000
July $\$ 1,1915$

(Par value)

$\$ 163,129,850$

$5,608,850$

$511,437,356$

$24,632,292$

$160,288,700$

$180,590,850$

$1,150,339,130$

$25,253,201$

29,000

$2,201,000$
$\$ 120,597,750$

$4,858,650$

$336,761,704$

$9,070,955$

$74,796,900$

$85,166,470$

$774,793,834$

$7,788,300$

836,000

958,000

A perusal of the above table indicates the extent to which Europe has sold her American securities in order to finance her extraordinary purchases in this country. It should be noted that 
this comparison only partially reveals the extent of European liquidation. It deals only with bonds and stocks in the names of foreign holders. It does not cover the sale of foreign owned securities which have stood in the names of American bankers, brokers, or institutions and which are generally believed to aggregate an enormous total, nor does it take into consideration the sale of listed industrial securities or of securities issued by small industrial concerns. Without considering the additions which would be represented by these unknown elements, the total is nevertheless staggering:

\section{Reduction in Holdings}

Reduction:

Jan. 31,1915 to July $31,1915 \ldots$...

July 31,1915 , to July $31,1916 \ldots$
In par value

$\$ 480,892,135$

$807,881,666$
In market value

Not stated

$\$ 641,338,822$

Total

$\$ 1,288,773,801$

Presuming for the moment that foreign holders receive, on the average, par for securities sold, which is unlikely, and adding the total par value of the railroad securities disposed of to the face value of government bonds sold in this country and to our net importations of gold, we find that we have accounted for the $\$ 2,500,000,000$ of abnormal purchases arising out of the war:

Net import of gold.

$\$ 462,000,000$

Foreign government and bank loans made in America $900,000,000$

European securities resold in America.

$1,288,773,000$

$\$ 2,650,873,000$

\section{Mobilizing These Securities}

As a matter of fact, the mad rush of war expenditures in America exceeded the rate of liquidation of foreign-owned American securities. In spite of the necessities of European business men who must deplete their strong boxes in order to liquidate the losses and repair the crippling effects of war, in spite of the forced sales of American investments by foreign families left without sufficient income while their bread-winners were at the front, and the sale of securities by widows and orphans in closing estates or financing their needs, the stream of liquidation must needs be quickened by governmental pressure. With the American market displaying unmistakable signs of a limited capacity for European governmental 
loans, and faced with the prospect of undermining foreign banking systems through continued withdrawals of gold, the allied nations were forced to use pressure to accelerate the disposal of American securities owned by their citizens. Out of this necessity was born the British mobilization plan in January, 1916. The plan in brief provided for the mobilization, or concentration in the hands of the British government, of American securities owned by its subjects. The holders of such securities are given several options. The first option provides for the sale of American securities to the British government, payment being made in British exchequer bonds at specific prices fixed from time to time by the government. The second option makes provision for holders of American securities who, for any reason, are not prepared to sell them. From such the British Treasury is willing to accept the securities on deposit subject to a right of purchase on certain contingencies. The government in effect borrows the securities for a period of two years. While on deposit, the lender of the securities is to receive the interest and dividends paid in respect to them, and also, by way of consideration for the loan, a payment at the rate of $\frac{1}{2}$ or 1 per cent per annum, calculated on the face value of the securities.

The securities acquired through the British mobilization plan can be used for two purposes: first, to sell in the American market in order to build up banking credits. Doubtless many securities have been so used. Such sales have been made quietly and unobtrusively, and it is impossible to measure their extent. Second, American securities thus acquired are pledged for loans in America, made either by banking institutions or through the flotation of bonds and notes by investment bankers. Numerous short-time credits with American bankers have been made by foreign banks or governments using such securities as collateral.

\section{Other Recent Devices}

Of late, subsequent to the period covered by our inquiry, England and France have taken to financing themselves on an extensive scale through the aid of these securities. The French plan is the creation of an American corporation known as the American Foreign Securities Company, which has issued a collateral loan of $\$ 100,000,-$ 000 , represented by 5 per cent three-year gold notes of the corpora- 
tion secured by the pledge of $\$ 120,000,000$ of securities made up as follows:

Approximate Value at Prevailing Prices and Then Existing Exchange RATES

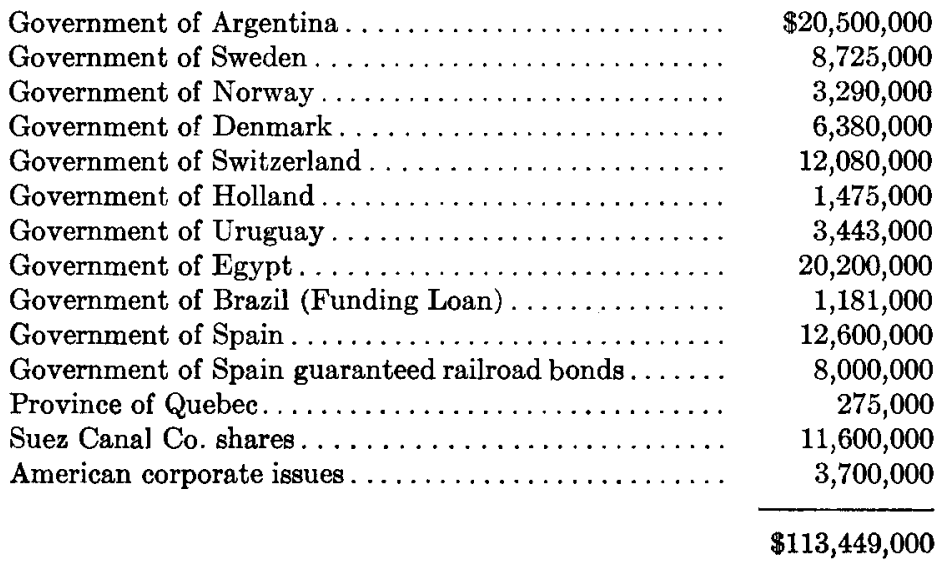

The British government in August, through a syndicate headed by J. P. Morgan \& Company, floated a $\$ 250,000,0005$ per cent twoyear loan representing the direct obligation of the British government and further secured by the deposit of $\$ 300,000,000$ of collateral to be made up as follows:

Group 1, Stocks, bonds and other securities of American corpora-

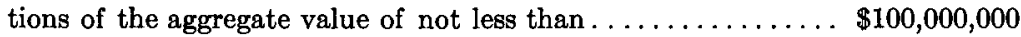

Group 2, Bonds or other obligations of the Government of the Dominion of Canada, either as maker or guarantor, and stocks, bonds and other securities of the Canadian Pacific Railway Co., of the aggregate value of not less than $\ldots \ldots \ldots \ldots \ldots \ldots \ldots \ldots \ldots \ldots$
roup 3, Bonds or other obligations of the several following govern$100,000,000$ ments, either as maker or guarantor, to wit: of Argentina, Chile, Norway, Sweden, Switzerland, Denmark and Holland, of the aggregate value of not less than

$100,000,000$

Two significant tendencies are to be noted in these loans: first, the constantly more favorable basis as regards price and interest rate at which succeeding financing is done. This tendency will doubtless continue in future financing. Second, the recognition by the foreign governments of the necessity of pledging collateral in order to attract American investors-a distinct departure in methods of 
war financing. It is important to note that a large proportion of the collateral pledged is itself not readily salable in American markets. There is no American market, generally speaking, for the bonds of Chile, Norway, Sweden, Denmark or Holland. It would be even more difficult to sell advantageously in American markets the securities issued by the governments of Uruguay, Egypt or Spain.

By pledging this collateral, however, with a sweetening of from 3 per cent to $33 \frac{1}{3}$ per cent of American securities, England and her allies are postponing the day when they will be face to face with the exhaustion of this most precious method of financing war purchases. England is jealously husbanding her American collateral. She is paying it out as a miser might do, foreseeing that she must finance war purchases from us for a long period of time. The sale of loans secured by collateral, which in itself would be unsalable, postpones the day of exhaustion of her supply of standard securities which might thus be sold. It requires no mathematician to see that if the liquidation of American securities by Europe continues at the rate heretofore prevailing, these resources will be exhausted before January 1, 1918. The happening of this contingency prior to the termination of the war opens up a financial problem the contemplation of which is not pleasant to English bankers.

America is rapidly getting out of debt. It would have required generations for us to have accomplished what is occurring in a few brief months. We are like a family who, through fortuitous circumstances, is enabled to pay off the mortgage on a house. It will soon be unnecessary for us to send abroad merchandise and commodities of various kinds, exceeding our purchases by some $\$ 250,000,000$ per annum, in order to pay the interest upon our indebtedness. The effect of this situation upon our future international trade does not fall within the scope of this discussion. It should be pointed out that England has been undermining at an appalling rate her tremendous financial strength. As Mr. Francis Hirst, for many years editor of the London Economist and one of the leading financial authorities of England, has pointed out, it is doubtful whether, in the long run, England would have gained had she been unable to effect such enormous war purchases in America. Mr. Hirst advances the opinion that England has done Germany a real service by blockading her. She has forced the Teutonic allies to be self-sufficient; to go in debt to themselves rather than to foreign nations to produce 
the materials of war. History will demonstrate whether this view is correct.

\section{The Significance of What Has Occurred}

The significance of the liquidation of England's holdings of American securities can be briefly stated. England and her allies cease to have the right to share in the productive capacity of America. As the holder of mortgage bonds, entitled to a fixed rate of return, or a prior share in the profits of American production, and as the owners of stock in American corporations, they have enjoyed for years the right to draw upon this country for a large share of our annual production. These earnings have been in part reinvested, so that for many years the amount of goods which had to be exported to European owners and creditors steadily increased. Today European investors have exchanged the right to a large share of the production of America for the promises of their own governments to pay principal and interest. Instead of receiving countless shiploads of grain, cotton, meat and manufactured articles in payment of interest upon these investments, the annual returns must be raised by taxation of themselves. Looked at from the broadest economic viewpoint, England and her allies are shooting away, upon the fields of France and Belgium, their claim to an imperial share in the railroads, steel mills and other productive plants of the western world. 